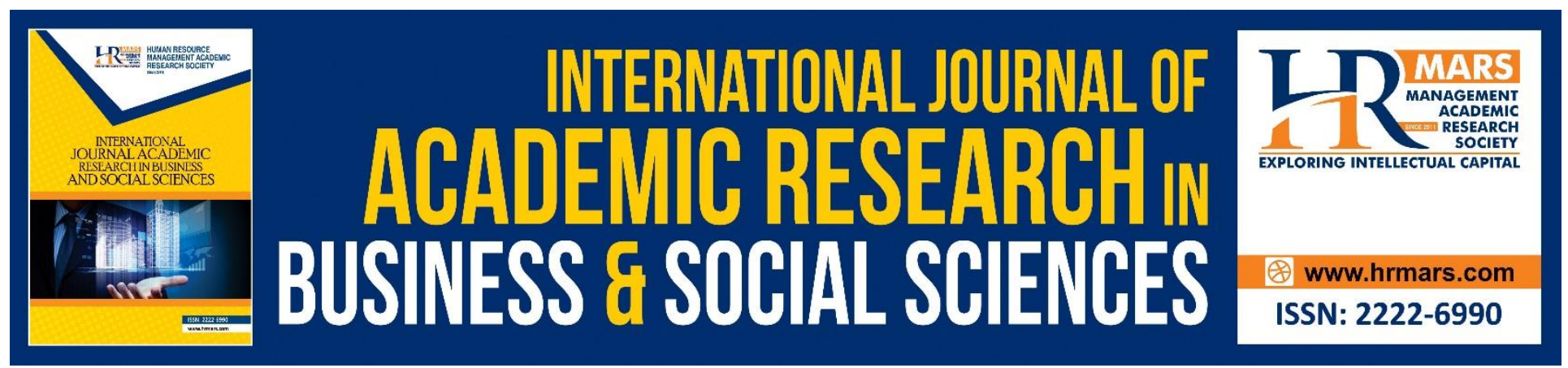

\title{
Factors Leading to Interpersonal Relationship with Pengkid/Butch: Femme Women Role Player Perspective
}

\author{
Alice Nurizza Ab Aziz, Abdul Razak Abdul Rahman, \\ Wan Munira Wan Jaafar, Mohd Ibrani Shahrimin Adam Assim
}

To Link this Article: http://dx.doi.org/10.6007/IJARBSS/v9-i2/5653 DOI: $10.6007 /$ IJARBSS/v9-i2/5653

Received: 11 Jan 2019, Revised: 17 Feb 2019, Accepted: 30 Feb 2019

Published Online: 03 March 2019

In-Text Citation: (Aziz, Rahman, Jaafar, \& Jaafar, 2019)

To Cite this Article: Aziz, A. N. A., Rahman, A. R. A., Jaafar, W. M. W., \& Jaafar, W. M. W. (2019). Factors Leading to Interpersonal Relationship with Pengkid/Butch: Femme Women Role Player Perspective. International Journal of Academic Research in Business and Social Sciences, 9(2), 949-960.

\section{Copyright: (C) 2019 The Author(s)}

Published by Human Resource Management Academic Research Society (www.hrmars.com)

This article is published under the Creative Commons Attribution (CC BY 4.0) license. Anyone may reproduce, distribute, translate and create derivative works of this article (for both commercial and non-commercial purposes), subject to full attribution to the original publication and authors. The full terms of this license may be seen

at: http://creativecommons.org/licences/by/4.0/legalcode

Vol. 9, No. 2, 2019, Pg. 949 - 960

http://hrmars.com/index.php/pages/detail/IJARBSS

JOURNAL HOMEPAGE

Full Terms \& Conditions of access and use can be found at http://hrmars.com/index.php/pages/detail/publication-ethics 


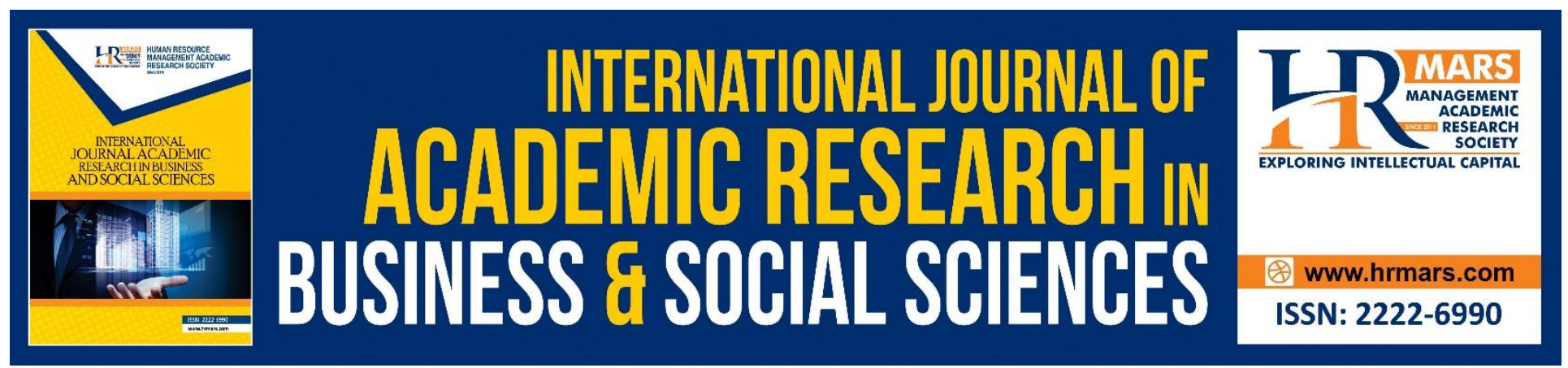

\title{
Factors Leading to Interpersonal Relationship with Pengkid/Butch: Femme Women Role Player Perspective
}

\author{
Alice Nurizza Ab Aziz, Dr. Abdul Razak Abdul Rahman, \\ Dr. Wan Munira Wan Jaafar, Associate Prof Dr. Mohd Ibrani \\ Shahrimin Adam Assim \\ Department of Social and Development Science, Faculty of Human Ecology University Putra \\ Malaysia
}

\begin{abstract}
The phenomena of homosexual relationship have become common challenging Malaysian status as an Islamic nation, called for a serious attention. This behavior needs to curbed to ensure that such homosexual relationship be arrested comprehensively and practically with widespread specific on this issues. However, most studies focus on "Pengkid/Butch" which is a female lesbian as a "male role player" and the" female role player", "femme", which is actually a lesbian women, maintaining their female characteristics and partnered with the "Pengkid" or "Butch", In view of that, the focus specifically to the female femme which involved actively in interpersonal relationship "game play" as it is seen as overlooked by community compared to Pengkid as a dominant character. In order to acquire in depth information and understanding, semi structured interview has been designed and 10 of Malays Muslims respondents within Federal Territory, Kuala Lumpur and Selangor have been interviewed. Results of shown that the Femme group is active and the driven factor in the interpersonal relationship attributed by 6 main factors. Resultant of this revealed that interpersonal relationship is stronger ever though, the satisfaction and orgasm is limited and against the natural human biological and sexual desires. This provides a new frontier of understanding from the femme behavioral perspective and recommended that an appropriate criteria/methodology to arrest as well social support be thought of to render help to this group of community.
\end{abstract}

Keywords: Femme, "Pengkid", Interpersonal Relationship, Factors 


\section{Introduction}

"Femme" is a term refers to and used in Lesbian community as a lesbian women maintaining their maidenhood characteristics while in relationship partnering with "Pengkid" or "Butch" ie a term referring to in the context of lesbianism to lesbian women depicts a "male role player", behaving, acting as male partner and female with femme women in interpersonal "love-affair" relationship (Nora Hendon,2011; Heidi et al,2003). This homosexual relationship behavior occurs in isolated clusters in any institutions of community. Though, related to "Pengkid" is more dominantly done, in comparison to "Femme", due to the fact that the "Pengkid" role players are conspicuously seen and exposed in the public and community than that of the "femme" women players. In view of that, this specifically emphasize in exploiting femme perspective in closer angles in acknowledging their interpersonal relationship behavior and activities in their life. This also ventures into femme levels of satisfactions with "Pengkid" in Malaysia to provide a proposal of "intervention" to these issues relating the group on the whole. Apart from that, this would possibly provide a vocabulary and literature regarding femme in a more widespread understanding inclusive of interpersonal relationship within this group of community.

\section{Previews of Past Studies.}

Academic studies comprehensively in the past, regarding femme were not fully sufficient or complete by the past researchers, make this to provide a contributive literature filling up the vacuum, if not completely full filling for future generation search and value-added branch of societal understanding and behavior in sociology. Most studies focus and revolved around "Pengkid". We need to be reminded that femme too is major contributive factor attributed to this homosexual behavior, Furthermore, femme externally from lenses of society seem to be normal group of community, but internally, they are group of community in a society which possesses deviant needs and homosexual desires not known or grasp externally.

\section{Recognizing Femme}

Past writings/literature on femme were few, due to perhaps least understanding not really acknowledged the difference of femme categorization as to whether they belong to the heterosexual or homosexual group or community. Though, physically, expert researchers would be able to identify femme behavior externally as lesbian, but not on its "ontological essence" categorization or her socio-cultural behavior norms in their relationship thus, not being able to find out solutions as whose is and identity of femme (Carter and Noble, 1996). In referring to a book entitled "The Femme Mystique", it could not even define the concept of femme itself. Queer and Feminist theories itself are not able to synchronized and define appropriately the concept of femme itself. What is written in the book automatically denied the conceptual understanding of femme unaware.

Newman (1995) suggested in the related matter that every femme possesses her own mystiques that is, confusion in identifying their own entity and lesbian behavior. Accordingly, Newman proposed be yourself and not depicting others or to be like others. In other words, if your orientation inclines to 
be a beautiful sexy women, be one and be a lesbian femme with relationship amongst femme women and if you are incline to a butch entity so be a lesbian with a femme entity with relationship amongst butch. There exist confusion amongst femme when they feel that they are femme but not sure as to whether they should incline in relationship with beautiful women ie femme or butch, a "male role player", because of the categorization that they are women and "sand witched" between being a feminine women, while also being a lesbian. Femme group is amongst those who underwent great depression and stresses in searching and identifying their entities in the context of lesbian multi categorization on the whole.

Eves, (2002) belief that the main issue on femme behavior and characteristics is the uncertainty in sex (gender) and choice that leads to what they are and their role player in "game play" of femme. It's as if femme is called for in "changing characters and role" in the lesbian culture defining their maidenhood as such "gender conformity" where femme maintain their biological women-hood status.

Most femme in reality confronts uncertainty of sexual entity allowing changes in different context in parallel with their sexual orientation. This reality supported by a done by Diamond (2008) who belief that a lesbian identity is always subjected to change and never a rigid phenomenon.

This uncertainty and instability defer from person to person, where some are on a higher scale while others are lesser. An example can be sought out from those who are of heterosexual sexual orientation surrounded by sexual gender alike, possibly inclined towards same sex and romantic feelings amongst them. Applying same to other social behavior, sexual preference, characters and identity can always change and flexible to a certain level and satisfactions.

Diamond (2008) also belief that this sexual uncertainty and instability is attributed by experiences and exposures of the women sexualities throughout their life time, that need further closer understanding and in depth. The debate is always open for any challenging assumptions that "unchanged sexual orientations" that brought about the categorization of heterosexual, lesbian, gay and bisexual.

As such, identifying conducive factors leading to femme to establish homosexual relationship with "Pengkid" needs more in-depth frontier of. There are various factors attributed to the women orientation urge on interpersonal relationship with "Pengkid" which challenge a new frontier of detail understanding exploring its country of origin, religion, community and race.

\section{a. Biological}

Behavioral characteristics of homosexual relationship are related to biological treats of a person. This factor is supported by a biological theory. This theory as explained by Feldman and Mac Culloch(1980) that revealed that biological influence is strongly related to homosexual appearance. Early studies of the fifties related to homosexual amongst twins had shown evidence that homosexual is a hereditary. There is also valid evidence on how hormone influences the development of human brain of different sex. Physiological influence by chromosome and hormone is obviously observed on the fetus while still in mother's womb 
and in puberty development. This would show that at the pregnancy stage (baby boy) and the mother produced less of male hormone (testosterone), this can attribute to the male child behavior, thinking process, influence inclined towards women character and behavior, though, his male characteristics remain intact(Mohd Tajudin, 2003 ). However, there aren't any overall holistic complications on this contributing factor especially from the femme perspective.

\section{b. Environment}

Influences of social exposures and environments by societal institutions such as parents, local community, learning institutions like schools and colleges, and media play an important pivotal role in shaping and molding characters, behavior, of the young generations. Misunderstanding and confusions of gender can arise out of these societal institutions failure to help build and nurture the appropriate sexual identity of the young. A young male child who has been pampered and soft in behavior for example, lack of aggressiveness, introvert in characters whose hobby prefer domestic chores, would most likely in his growth development inclined towards a feminine sexual identity. Whilst his opposite young female child, allowing them to be tough, aggressive, involved in sporty games, unaware through her development growth inclined towards manhood characters and behavior if parenting care persist throughout this young critical growth(Mohd Tajudin, 2003).Social learning curve as suggested by Albert Bandura( in Jas Laile, 2002) revealed that a child learn on their sexual gender through their parents as most parents guide their children on an appropriate platform suiting their sexual gender; and through the child observations and emulating on their peers suiting their own sexual gender model. In some male child, comprising of more sisters than brothers, would likely has the tendency of bending towards his surrounding sisters' behavior and routine activities, at homes or in the public. In this kind of situations, parents play an important roles in guiding an appropriate platform to ensure the child sexual identity are taken care off in his/her developmental growth, if otherwise, the child can turn out to be "Mak Nya"(Marziana \& Mimi Sofiah, 2014).

\section{c. Friends and Peers Influence}

Social learning curve theory descripts the very fact that peers/friends of same age help in determining the healthy development of one sexual identity, made by Nor Ba'yah and Yahaya(2002) found that getting along with friends/peers of same age(socialization process) has influenced on behavior of transsexual if the male respondent is encircled by a women friends/peers in comparison to male and likely to be a "Mak Nyah". Marziana and Mimi Sofiah, 2014 in their observations also found that male with women friend/peers outnumbered male, most cases will portray the image, behavior, and thinking process alike of female of same age including sexual orientation.

\section{d. Life experiences}

Freud (1971) descripts that his patient(female) had shown a male behavior due her past experiences with husband that had hurt her previously, from this theory, it can be deduced 
INTERNATIONAL JOURNAL OF ACADEMIC RESEARCH IN BUSINESS AND SOCIAL SCIENCES

Vol. 9, No. 2, Feb, 2019, E-ISSN: 2222-6990 C 2019 HRMARS

that a women past experiences in the childhood times such as sexual abused, and male's discriminations can surfaced as hatred on men. In parallel, the feeling of insecurity with men relationship and thus the choice of same sex relationship, i.e. women.

\section{e. Others}

Based on previous literatures, there are 4 factors had been identified possessed by "Femme" proven to be conducive for the behavior of establishing homosexual relationship with "Pengkid". However, most of these studies of are of foreign in origin and studies in Malaysia are in its isolations. On that score, there would be more other factors that are yet to be identified of variant in nature in accommodating the specific countries involved and the societal open mind set of the countries.

\section{Methodology}

There are 10 numbers of respondents involved in this, mostly from Selangor, Negeri Sembilan, Melaka and Kuala Lumpur. Respondents comprised of various background and profession/careers. The common values are, they are Malays and Islam/Muslims. These values chosen to specifically gather information on type of race, religion to find out ways to curb this confusion and uncertainty in the context of race and religion.

In order to gather detail information, this study designed a semi structured interview aiming at more widespread information from the respondent. Sampling technic is done through purposive sampling. This is to ensure that samples collection meet the directed target topics on education (religion and normal education), careers, religion and parents/family background (Sekaran, 2003). This is done as such to avoid any elements of bias against on any elements presented. This structured interview has been carried out on volunteers' individuals. Snow Ball technique has been applied in this study as it's a procedure in social science study where the ready and the real respondent or subject willing to recruit another respondent or subject from their community or friends to get the same information as needed by researcher. (Nora Hendon, 2011; Ahmad et al, 2015

Results out of the interviews converted into interview scripts. Subsequently, researcher would identify key words adopting the information search for. In parallel, key words would be classified in accordance to study sequencing or additional items then identified.

\section{Findings}

\section{Respondents Demography (Femme)}

Out of $100 \%, 80 \%$ of them are bachelors, whilst $20 \%$ once married but are now divorcee. Generally, they are on thirties, and femme respondents educational levels at the early stage were university/college graduates in its compositions with the SPM school leavers together constitute $30 \%$. Type of schools where respondents came from are recorded to establish its relationship with the respondents. These comprised of $70 \%$ co-educational schools (co-exist male and female) whilst, $30 \%$ comes from normal single sex (female) schools. 
INTERNATIONAL JOURNAL OF ACADEMIC RESEARCH IN BUSINESS AND SOCIAL SCIENCES

Vol. 9, No. 2, Feb, 2019, E-ISSN: 2222-6990 C 2019 HRMARS

Femme Respondents physical aspects also recorded to acknowledge how it relates to "Pengkid" desirous needs. $100 \%$ respondents have been categorized as beautiful women. However, $80 \%$ of them possessed a sexy slim body, and $20 \%$ quite plump.

\section{ii. Contributive Factors or Criteria for Femme in Establishing Relationship with "Pengkid"}

\begin{tabular}{|l|l|}
\hline Factors & $\%$ \\
\hline Love, Caring, Softness from “Pengkid” & 100 \\
\hline Loose Religious Understanding and Education & 100 \\
\hline Bitter Treatments Experienced With Men & $80 \%$ \\
\hline Friends/Peers Influence & $50 \%$ \\
\hline Biological & $30 \%$ \\
\hline Environments & $10 \%$ \\
\hline
\end{tabular}

Table 1: Contributive Factors/Criteria on Femme Relationship with "Pengkid"

\section{a) Love, Caring, Softness from "Pengkid"}

Interviewed done with all respondents recognized that their "Pengkid" lovers are soft, caring, understanding and receiving the best treatments in comparison to male of their past experiences and currently. This perspective of conduciveness drives to be a major factors for femme to continue establishing relationship with "Pengkid" thus get themselves hooked up with Lesbianism recording $100 \%$ of respondents statement.

.... "I' am comfortable with my "Pengkid" treatments and caring. Sham will always do the best for me, she is very understanding, possibly because she is also a woman, so of course she understands better"

"....Men are always sluggish and not attentive to women feelings. Example if I hint insufficient money, he would not listen much. He would reply request from farther and the conversations stop there. But with my "Pengkid" just mentioned no money, shortly in few minutes it's bankin into your account".

...."Why can't men treat women with tenderness and lovingly? I have experienced once from a man who treated me badly, I hate this kind of treatment. He was not even romantic, and yet selfish, and I 'am the one who always need to care our relationship, I' am fed-up and exhausted!"....

b) Loose Religious Understanding and Education

All the respective respondents are aware that their relationship with "Pengkid" is against the covenant of religion and norms of social ethics. Though, despite the awareness of their wrong doings, the urge to continue the relationship persist. This provides the evident that Femme possessed loose religious understanding and education resulting in their obscene participation with respondents recording $100 \%$ involvement. 
INTERNATIONAL JOURNAL OF ACADEMIC RESEARCH IN BUSINESS AND SOCIAL SCIENCES Vol. 9, No. 2, Feb, 2019, E-ISSN: 2222-6990 C 2019 HRMARS

"....l' care no more what people would talk about, it's not they who's to burden all the Sins.."

"...If it's not because of religious covenant I would have chosen "Pengkid" as life Partner.."

"...l' am aware that as a Muslim I have done a sinful act, and hope l'll change for good in the future, if I were to receive and acknowledge Allah's Mercifulness..."

\section{c) Bitter Treatments Experienced with Men}

Some of the respondents conveyed their bitter treatments experienced with men that pursued them to have chosen "Pengkid" as their Partners. Bitter experiences such as sexual abused, irresponsible men, fed-up, sluggishness, roughness, hastiness, are some of those bitter experiences told during the interview sessions with the respondents. These bitter experiences recorded $80 \%$ of the respondents interviewed paved way for alternative partnership, ie with "Pengkid" which is more understanding, caring.

..." Men what's in their mind 24hrs is always sex. In some cases, just met, yet to be a couple. If we request some small favor or any un expensive items, their demand is always our body"....

.."Most men will talk same things all the times and insensitive to wife's feeling, fed-up and lack romanticism. "Pengkid" on the hand, if I mentioned the hand bag is beautiful, all you know next week you'll get the bag. But with men not until you're conformed as couple, never dreams that they will invest on you"....

.."I get involved with "Pengkid" since I was a divorcee, I' am boring with past experiences that's why get closed intact with "Pengkid"..."

\section{d) Friends/Peers Influence}

Friends/Peers influence in social activities, life is unavoidable generally. Respondents expressed the fact that befriended with "Pengkid" have influenced their inclination to have an interpersonal relationship with "Pengkid". Though, at early stage it's a reluctance feeling to this homosexual relationship, over times it appeared to be a lover's relationship. $50 \%$ of respondents agreed that their involvement and socialization with "Pengkid" attributed to their homosexual behavior and activities.

..."Earlier, I was not having any interest and ridiculed this kind of homosexual behavior. But when I get closer as friends with them, found it's not bad either, finally tends to be a normal 
INTERNATIONAL JOURNAL OF ACADEMIC RESEARCH IN BUSINESS AND SOCIAL SCIENCES Vol. 9, No. 2, Feb, 2019, E-ISSN: 2222-6990 C 2019 HRMARS

.."The "Pengkid" girlfriend always talked about the joy and happiness with "Pengkid". I observed they're always happy and money is always available, most items bought are branded and expensive items..."

..."I allowed myself to befriend with them till I felt to try to have a relationship with "Pengkid"..."

\section{e) Biological}

This statement revealed that the Femme biological aspects that is, the developmental growth of Femme life has attributed to this homosexual behavior. $30 \%$ of respondents concurred that due to their parents/care taker busyness and lack of full attention on them during their tender and teenage age have shaped what they are now.

..." Grandma always scolded me if I mingled around with men. She worried if any bad things would have happened to me. My grandma always talked to me "you're beautiful, but if once spoiled it's useless, care after yourself, you have nothing to lose if you don't befriend with those young men..."

..." I never conveyed to mother anything. I must be able to take care of myself, helping mother to take care of the young and would never hope of demanding any things..."

..." From childhood my mother always ridiculed men as being bad and pointing out my father as an example..."

\section{f) Environments}

$10 \%$ of respondents related environments as a factor that brought them in contact with "Pengkid". Environmental refers to Schools, Institution of Higher Learning, and Works Places, where you can find "Pengkid" in them. In these situations where initially, it was just a normal friendship and over times have become almost casually and mutually understanding and there after became a norms. Furthermore, the situations normally dominated by them

("Pengkid").

.." In the old days of my schooling there're no boys in my school, in any kind of activities, acting, camping, its girls that would do the lead as boys/men, especially the tomboys..."

.."In my college life I observed there're couples of this kind. At first, I just want to know what are these couplings all about, it's of same sex, so what's so special."

..."During my working life I met with this tomboy, I became a close friend to her, until I get involved with her soft, tender invitation.." 


\section{Discussions}

Generally, this study has identified 6 main factors leading to as to why "Femme" women established relationship with "Pengkid". Loving affairs and soft and tender treatments rendered by "Pengkid" as some of major factors attributed to this homosexual relationship existence. Comparison of treatment by "Pengkid" as to that of men conspicuously is beyond compare where men are not as great as always thought off and which is championed by "Pengkid" in deep-rooted understanding of what women's wants and desired for in reality. On top of that, "Femme" women active involvement with these homosexual affairs is also attributed to their loose understanding of religious principles and its applications in life, thus, behaving and acting beyond the parameter norms of its principles and covenant. Study has shown that strong religious understanding and education can help one avoiding any unbecoming behavior or acts that are against the norms of religious values and society. Those individuals who up hold religious values can possibly evaluate what is right and wrong before acting on or involved in anything (Khadijah Alavi et al.,2012). Acknowledging religion is the first phase of human knowledge on "know what", followed there after religious understanding, "know how" is the next phase to be ventured. This is where the knowledge learned is applied and practice in routine daily life. Subsequently, phase "how to" is the exploration phase where knowledge and understanding within us to be sustained and its used and application maintained. These vacuum phases that have attributed to the loose religious understanding and its principles which confront this "Femme" group, though, acknowledged that fact that such relationship is against the norms of religion and society.

Generally, $80 \%$ of respondents do have earlier relationship with men and most of them have undergone bitter experiences with men pursued them bending towards a relationship with "Pengkid", The situational scenario drawn by respondents were that men were irresponsible, boring, and lack of appreciation and do not value women. This stigma should be corrected as not all men are of the type pictured by women and in parallel, women too have to be prepared and equipped with an appropriate knowledge and a backdrop understanding before getting along or befriended men and be part of dreamed partner and heart felt lovers. Without any appropriate prepared knowledge and understanding these issues and stigma will attribute to the "make-belief" jargon or slogan that men are irresponsible group in the community. Further to the unhealthy, anti-social surrounding of friends or peers would enhance the doers to be in that isolated, minor group of lovers-relationship of the "Pengkid". Lack of appropriate knowledge, limitation and parameters in friendship, un controlled behavior, would prepared the doers involved in isolated problematic groups that have dragged Femme in the continuous life of homosexual activities and behavior. Having said that, biological factor as a contributor factor to this phenomena, it's something we can't denied and it revolved around the failure of Parental care and Care Taker during the developmental growth of an individual at its Tender and Teenage age, leads to possibility of this isolated groups to be carried away in life without a navigator and right destinations. None the less, human as thinking creatures would 
always have the ability to make a choice of what is right path and wrongs doings that physically differentiate the demarcation border of man and animals. Vacuum in educational opportunities, times, loving, tender care and attentions are created factors to allow individual lust and desires jumped and involved in these homosexual activities and behavior apart from those governing factors discussed earlier. Closed knit environments only dedicated to this isolated community as against an open world of exposure to men further enhance the situations of grieves, depressions, hurts, that requires tender caring and consolations amongst some women have driven them to make a choice on these homosexual behavior and activities. Somehow or rather, some respondents whose parents/family that acknowledged their homosexual behavior do warned and advised them, but without any avail. This goes to shows that Parents and Family do have an attentive act on femme to make an appropriate choice in life and not to be confused by what they heading for in life.

\section{Conclusion and Recommendation}

There are various conducive factors that have pursued Femme women to established relationship with "Pengkid". These findings have identified 6 major factors that allow this to happen. However, factors relating to loving affairs and soft, tender treatments from "Pengkid" and loose religious understanding have become major factors recording $100 \%$ of respondents' conformation on those at issues for the Femme interpersonal homosexual relationship with "Pengkid". However, not all of those factors are of necessity for Femme to perform this homosexual activity. All these factors combined can be independent isolated factors without any interdependent roles on other factors. As such, each and every factor must be treated independently with a various approach that require holistic intervention to curb these issues.

In parallel to that, authorized agencies need to exercise a firmer action in dealing with these lesbian issues whilst, family institutions need be strengthen and muscled up because it's one of the important agencies in human capital investment capacity for excellency. The lead role family members whether parents (farther and mother) or spouses to be play a good role player to ensure that their children and family members achieved loving caring and appropriate attentions all the times.

Religious education too needs to be considered seriously in developmental child's growth right from their tender, teenage, to adulthood growth. Lacking of religious understanding and education would attribute to low probability of coming back normal to most adulthood situations (Batson et al,.1993). To some who have been involved with those unfortunate situations, they are always welcome to come back, attending those religious/spiritual programs abundantly available in Malaysia. Indirectly being able to cleanse oneself spiritually and fear of Sinful acts and doings. With the roles involved by various interested parties, it helps support from early stage to Femme involvement levels to change and enhance for betterment in the future. 
INTERNATIONAL JOURNAL OF ACADEMIC RESEARCH IN BUSINESS AND SOCIAL SCIENCES

Vol. 9, No. 2, Feb, 2019, E-ISSN: 2222-6990 C 2019 HRMARS

\section{Acknowledgment}

I would like to thank Allah for his never-ending grace and mercy throughout my writing.

Thank you to my parents, supervisor and committee members from University Putra

Malaysia.

\section{Corresponding Author}

Abdul Razak Bin Abdul Rahman

Department of Social and Development Science, Faculty of Human Ecology University Putra

Malaysia-arazak@upm.edu.my

\section{References}

Batson, C.D., Schoenrade, P. \& Ventis, W. L. (1993). Religion and the Individual: A Social Psychology Perspective. New York: Oxford University Press.

Carter, C. \& Noble, J. (1996). Butch Femme, and the Woman-Identified Woman. Open Journal system, 16,24-29.

Diamond, L. M. (2008). Sexual Fluidity Understanding Women's Love and Desire. Journal of Women and Aging, Vol 26

Eves, K.S. (2002). Epistemology of the Closet, $6^{\text {th }}$ Edition. Long Angeles:University of Carlifornia Press.

Feldman, M. (1971). Neurohormonal Functioning and Sexual Orientation: A Theory of Homosexuality-Heterosexuality. In Ellis, L and Ames, M, A, Psychologycal Buletin 101,233-258.

Ninggal, M. T. (2003). Transeksualisme dan Hubungan Dengan Kecelaruan Gender dari Perspektif Psikologi. Kertas Kerja dibentang dalam Seminar Transeksualiti. Universiti Teknologi Malaysia Skudai.

Newman, L. (1995). The Femme Mystique.Boston: Alyson Publication

Nora Hendon. (2011). Unfolding the Lesbianisme Orientation Development Amongs Selected "Pengkid" Malays. PHD Thesis, University Putra Malaysia.

Sekaran, U. (2003). Research method for business: A skill building approach, 4th edition, John Wiley \& Sons. 